\title{
Commentary: A tree in winter: The case for arterial grafting in the diabetic patient
}

\author{
Paul Kurlansky, MD
}

\author{
From the Division of Cardiac Surgery, Columbia University Medical Center, New York, NY. \\ Disclosures: Author has nothing to disclose with regard to commercial support. \\ Received for publication Feb 5, 2019; accepted for publication Feb 5, 2019; available ahead of print March 11, \\ 2019. \\ Address for reprints: Paul Kurlansky, MD, Division of Cardiac Surgery, Columbia University Medical Center, \\ Black Building 210, 650 West 168th St, New York, NY (E-mail: pk2245@cumc.columbia.edu). \\ J Thorac Cardiovasc Surg 2019;158:1571-2 \\ $0022-5223 / \$ 36.00$ \\ Copyright (C) 2019 by The American Association for Thoracic Surgery \\ https://doi.org/10.1016/j.jtcvs.2019.02.023
}

\section{"I wonder if the snow loves the trees...it covers them up snug... "Go to sleep, darlings, till the summer comes again.” \\ — Lewis Carroll, Alice's Adventures in Wonderland \& Through the Looking-Glass}

Diabetic individuals currently comprise half the patients who have undergone coronary artery bypass grafting $(\mathrm{CABG})$ in the Society of Thoracic Surgeons database. The association of diabetes with cardiovascular disease is dramatic: Diabetic patients are 2 to 4 times more likely to have cardiovascular disease, and at least $65 \%$ will die of their cardiovascular disease. ${ }^{1}$ Because the nature of their cardiovascular disease tends to be extensive and diffuse, with multivessel involvement, ${ }^{2,3}$ numerous prospective, randomized, controlled trials have shown the benefit of CABG versus percutaneous coronary intervention in diabetic patients with multivessel disease. ${ }^{4-7}$ The general reluctance of American surgeons to perform bilateral internal thoracic artery (BITA) grafting is even more pronounced in the diabetic patient because of a heightened concern for deep sternal wound complications (DSWIs). Specifically addressing such concerns, the meta analysis of Zhou and colleagues ${ }^{8}$ informs us that compared with single internal thoracic artery grafting, BITA is associated with enhanced long-term survival and that with the use of the skeletonized technique, there is no increased risk of DSWI. Although a similar message was delivered by a previous meta-analysis, ${ }^{9}$ which sited many of the same studies, this updated review adds data from an additional 5 studies encompassing 125,542 additional patients, including 1 prospective randomized control trial. Although the data on DSWI support the concern for increased risk in patients with BITA, when limiting analysis to studies that documented a skeletonized harvesting technique, that difference disappears. Operative mortality is equivalent, although data on longer-term survival clearly seem to favor BITA grafting, even more so for those studies that performed

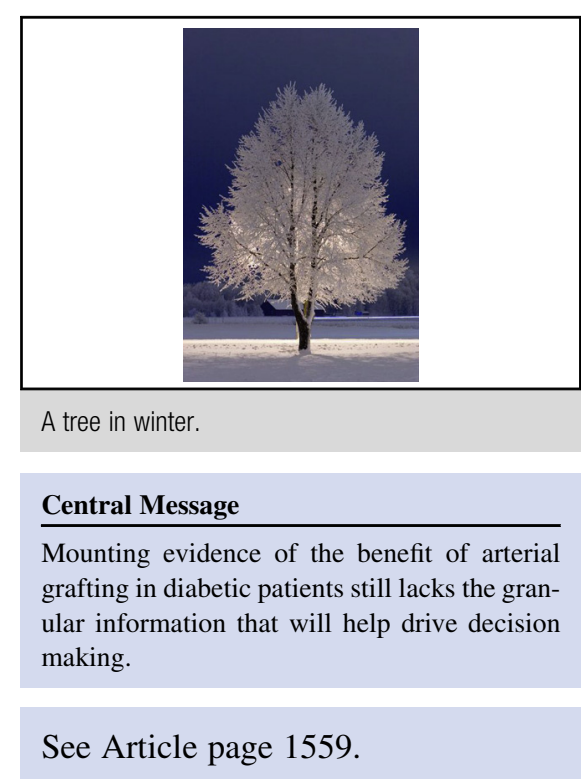

propensity matching and even further for those studies that reported cardiac-specific mortality.

One might argue that if retrospective studies are prone to bias, despite the best of statistical gymnastics, then metaanalyses of multiple retrospective studies may simply aggregate and exaggerate the impact of that bias, especially when the 1 prospective randomized control trial does not appear to corroborate the findings (although when analyzed according to "as treated" multiarterial grafting, that study also showed benefit ${ }^{10}$ ). For the clinician, the more compelling concern is how bare the branches still remain for informed decision tree analysis. Specifically which patients are the ones who do and do not derive a survival benefit from BITA grafting? What are the specific measureable elements that define improved survival? What is the time frame and quantity of that benefit? What is the patientspecific risk of DSWI and what is its current "utility" or quantitative measure that would enable balancing DSWI with death? Although much improved, the mortality associated with DSWI remains elevated, and the morbidity of additional procedures and treatments is considerable. What is the impact of different forms of diabetes-adult versus juvenile onset, insulin versus noninsulin dependent? What is the impact of chronic management (hemoglobin A1c) and optimal perioperative glucose management? Future research efforts should focus on providing the answers to these key unresolved issues so that our decision 
trees will bloom with patient-specific answers that will provide truly optimal surgical care for this menacing disease.

\section{References}

1. Cardiovascular disease and diabetes. Available at: https://www.heart.org/en/ health-topics/diabetes/why-diabetes-matters/cardiovascular-disease-diabetes\#. T07niXn16KI. Accessed February 4, 2019.

2. Norhammar A, Malberg K, Diderholm E, Lagerqvist B, Lindahl B, Ryden L, et al. Diabetes mellitus: the major risk factor in unstable coronary artery disease even after consideration of the extent of coronary artery disease and benefits of revascularization. J Am Col Cardiol. 2004;43:585-91.

3. Goraya TY, Leibson CL, Palumbo PJ, Weston SA, Killian JM, Pfeifer EA, et al. Coronary atherosclerosis in diabetes mellitus: a population-based autopsy study. J Am Coll Cardiol. 2002;40:946-53.

4. BARI 2D Study Group, Frye RL, August P, Brooks MM, Hardison RM, Kelsey SF, MacGregor JM, et al. A randomized trial of therapies for type 2 diabetes and coronary artery disease. N Engl J Med. 2009;360: 2503-15.
5. Farkouh ME, Domanski M, Sleeper LA, Siami FS, Dangas G, Mack M, et al. Strategies for multivessel revascularization in patients with diabetes. $N$ Engl $J$ Med. 2012;367:2375-84.

6. Kappetein AP, Head SJ, Morice MC, Banning AP, Serruys PW, Mohr FW, et al. Treatment of complex coronary artery disease in patients with diabetes: 5-year results comparing outcomes of bypass surgery and percutaneous coronary intervention in the SYNTAX trial. Eur J Cardiothorac Surg. 2013;43:1006-13.

7. Verma S, Farkouh ME, Yanagawa B, Fitchett DH, Ahsan MR, Ruel M, et al. Comparison of coronary artery bypass surgery and percutaneous coronary intervention in patients with diabetes: a meta-analysis of randomized controlled trials. Lancet Diabetes Endocrinol. 2013;1:317-28.

8. Zhou P, Peng Z, Zhiqiang N, Zheng S. Is the era of bilateral internal thoracic artery grafting coming for diabetic patients? An updated meta-analysis. J Thorac Cardiovasc Surg. 2019;158:1559-70.e2.

9. Kajimoto K, Yamamoto T, Amano A. Coronary artery bypass revascularization using bilateral internal thoracic arteries in diabetic patients: a systematic review and meta-analysis. Ann Thorac Surg. 2015;99:1097-104.

10. Taggart DP, Benedetto U, Gerry S, Altman D, Gray AM, Lees B, et al. Bilateral versus single internal-thoracic-artery grafts at 10 years. N Engl J Med. 2019;380: 437-46. 